\title{
National Awakening in Dhamtari before the First Arrival of Gandhi (A Study From 1900-1920)
}

\author{
Vipin Tirkey* \\ *Assistant Professor, Department Of History, Ggv Bilaspur, Cg.
}

\begin{abstract}
Through this paper the author intends to highlight the struggle of the Indians for freedom before the Independence. People prepared themselves to fight and die for the freedom of the country. They were much more spirited and motivated as they knew that there was an arrival of Gandhiji, who surrendered himself fully for the good cause of the nation.
\end{abstract}

\section{Introduction}

Before beginning of the Mutiny of 1857 Jamindar and people of Chhattisgarh region raised their voices against the policies of British Government. Therefore, time to time arose the revolts of Sonakhan Jamindar, Sambalpur and revolt of Hanuman Singh. But after the formation of Indian National Congress in 1885, it helped to awake more and more people of these areas, as a result through the various activities national consciousness was developed among people and thus they participated in all the movements. In first and second decades of $20^{\text {th }}$ Century because of prominent leaders of these regions a drastic change took place such as opening of khadi Ashram, Political Councils, National School etc., before the first arrival of Gandhiji in 1920. From 1900-1920 various political events took place in the Dhamtari areas which helped to develop national awakening/consciousness among people for the attainment of final goal that was the complete independence.

\section{Role of Indian National Congress}

In 1903, a branch of Indian National Congress was established in Raipur. In order to establish a branch here, Barrister C.M. Thakkar played an important role. One of the chief leaders of the Congress was Pt. Sundarlal Sharma. Shri Sundarlal Sharma came from Chandrapur village of Rajim area of Raipur district. In 1906, Pt. Sundarlal Sharma entered into Indian National Congress. ${ }^{1}$ In the same year 1906, Pt. Sundarlal Sharma formed "Sanmitra Mandal" in Raipur. Hundreds of people took membership in it. The main objective of the Mandal was religious reform as well development of national awakening. ${ }^{2}$ Pt. Sharmaji for the spread of Swadeshi, opened "Khadi Ashram" in Dhamtari, Rajim, Mahasamund and Raipur. ${ }^{3}$ Not only that, branch of Sanmitra Mandal was opened in Rajim as well in Dhamtari. ${ }^{4}$

In 1918, First Tahsil Political Council was held in Dhamtari in the courtyard of Janu

Hussain. The Chairman of Council was VamanBaliramLakhe from Raipur. In the council

Many people from Raipur and surrounding areas actively took part. Through this political council people were ready to achieve freedom. Sapreji was the chief leader of this district and created the atmosphere of political awakening.

By the great efforts of Congress leaders National Political Council was held in Dhamtari. There were many organization under prominent leaders at Tahsil level such as - Pt. Sundarlal Sharma(Rajim), Narayan Rao Medhawale, BabuChotelal Srivastava (kandel), DauAnjor Singh and DauDomar Singh as well advocate Muhammad Hakim from Dhamtari. ${ }^{6}$ Mahadev Rao Sapre was elected as president of the session. In this session he delivered speech and made aware about the political condition, consciousness and the aim of congress as Swaraj. ${ }^{7}$

\section{The First World War and Swaraj}

In this session many resolutions were passed as to help British Govt., In the First World War, demand of Swaraj and also national education. On the other hand C. M. Thakkar too put forward one resolution, which was supported by Lari Sahib and that was for the army of this nation and thus from this time onwards they will get a lot of rights as well under the Indian officers, national army will be organized. ${ }^{8}$

This resolution was also supported by the President of the session Madhav Rao Sapre and gave important speech that you are giving your words, now you have to give your hearts also; don't do slavery, God doesn't make two laws, England PM said that in the country of enemy also we will establish Swaraj. I ask to the English that we the people of Hindustan, what do we have become an enemy under you around 150 years. You have eaten the salt of Hindustan; therefore this is not a justice. ${ }^{9}$ Further he said,"Somebody says war is going on now, therefore Hindustanis should keep quite. But I say that what the problem is, if we ask Swaraj this time. We 
demand openly for it...we should get the right of Swaraj. It is against the rule that Indian armies will fight for England and we will be under English Officers."10

Sapreji had once demanded that British Govt. is not behaving properly with their colonies. It is also one of the reasons of unhappiness, and description should be finished in administrative matter. The speech of sapreji was an effective one and it helped to develop national consciousness among people through the council. This period was a Tikal phase and sapreji was one of the chief leaders of this era. In this session Vamanrao also put forward a resolution, which was supported by the Pt. Ravishankar Shukla, thus he said that unless and until British Govt. will not be agree to give swaraj, it will be difficult to help in the world war. ${ }^{11}$ Thus, it was an effective speech which was delivered by Madhav Rao Sapre.

\section{Protest of Rowlett Act 1919}

In protest of Rowlett act 1919, strike was taken in the nationwide. Thus, in Raipur, Durg, Dhamtari etc. leaders of this region addressed in the assemblies and procession took place. On $30^{\text {th }}$ March 1919 , public strike was held and decided to celebrate as a Black Day. In the following month on $13^{\text {th }}$ April 1919 , Jallianwala Bagh Massacre took place in Amritsar, under the guidance of General O'dyer. As a result of this place too arose their voice against British Govt. and accused for their evil act.

In the next month of Jallianwala Bagh Massacre in May 1919, Second Tahsil Political Council was held in Dhamtari Tahsil; under the chairmanship of Shri Ganesh Krishna. People of this tahsil welcomed to the chairman in such a way, which was a remarkable, in the welcome of these people was tremendous for the nation and many people from outside participated in the council. ${ }^{12}$ This council was held in the house of DauDomar Singh. In this council from Raipur Pt. Ravishankar Shukla, Madhavrao Sapre, Vamanrao Lakhe and Ram Dayal Tiwari etc. participated. ${ }^{13}$ On the other hand from Bilaspur E. Raghvendra Rao, Kunj Bihari Lal and Agnihotri as well from DurgDaduram, Ghanshyam Singh Gupt participated in the council. Thus many of them gave speeches too in the council. Because of the political council youngsters of this areas came in front as a SwayamSevak, and participated in the other councils also. Though all were tortured and punished by British Govt. their love for the nation was increasing day by day. The main topics of this council for discussion were Govt. of India Act 1919, Rowlett Act and JallianwalaBagh Massacre 1919. There presented all the leaders delivered speeches regarding on the above topics. In the words of Dr. Shobharam Dewangan that in the month of May 1919, Second Tahsil Political Council was held in Dhamtari. This council was held at the Nand dynasty's house of Dau Domar Singh. ${ }^{14}$

Once upon a time Gandhiji has said that the English Govt. is a Saitan govt., in order to get Sawraj we have to fight against them. The resolution of Non-Cooperation was passed in the Congress Session of Calcutta in 1920. Thus, Gandhiji was the chief leader of the movement and prepared some main programmes of the movement in order to attain Swaraj. It was a nationwide therefore, it affected Chhattisgarh region too; especially it was started in the most awakening village called kandel of Dhamtari Tahsil in Raipur district. Thus, from this village onwards Satyagraha started in 1920. The impact was seen in the Dhamtari Tahsil, according to programme of the movement boycott of schools, election and cloths were done by the native people of this region. Regarding the election matter, British Govt. declared for the election but nobody came in front for it. Besides this, in DhamtariTahsilBajirao Kridutt elected independently, later on he resigned. ${ }^{15}$ According to Dr. ShobharamDewangan, students of DhamtariTahsil contributed a lot in the Non-Cooperation Movement. Bisahu Rao Baber, who was the first year student of Nagpur College and Shankar Rao Hishikar who was a second year student of Medical College Raipur, left their studies and actively participated in the movement.

For the development of national awakening especially in the Raipur district many chief leaders, social institutes, Congress and Home rule league's concepts contributed a lot. All the chief leaders visited village to village and organized the assemblies etc. Thus all these efforts were seen in the farmers satyagraha which occurred in 1920. In 1920, at Kandel village of DhamtariTahsil farmers stared the Satyagraha against the British Govt. This movement was fully led by the farmers of this place. KeurBhushanji was written in his article that this Satyagraha was the impact of Chaparan Satyagraha of Gandhiji, because here too farmers led the Satyagraha on the basis of non-violence. ${ }^{16}$ Thus first example of the movement was seen in the Kandel village. Satyaghara of Kandel village was well known from 1920 onwards in the nation. ${ }^{17}$ Chief leader of the movement was - BabuChotelal Srivastava, along with his friends contributed a lot. ${ }^{18}$ The dams which were made on the Madamsilli this day also exists there. ${ }^{19}$ Through this dam's water all the villages of DhamtariTahsil was irrigated.

Kandel Nahar Satyagraha was successfully led by a great freedom fighter of this place BabuChotelal Srivastava, he was well known in the nation. British Govt. wanted to put down BabuChotelal Srivastava, later on he too was fined for the use of water. Many times Govt. tried to suppress down to Chotelal Srivastava, but couldn't get success. When the British Govt. accused falsely to villagers but by the God's grace on that night a heavy rain took place in all the areas of Kandel. ${ }^{20}$ 
British Govt. focused and tortured villagers to pay tax, thus as a result villagers decided to start Satyagraha. Following were the main reasons by which in the month of August, tahsil level Satyagraha started: 1. Department of irrigation falsely accused on villagers.2. Department of irrigation forcefully tried to get fined amount.3. For that villagers were tortured. ${ }^{21}$ People of Kandel village raised their voices against Govt. and refused to pay that sum of amount. Thus, in the Dhamtaritahsil, there was the anger and hatred atmosphere arose and Satyagraha was stared against Govt.On $1^{\text {st }}$ Sept.1920 an assembly was held at Kandel village in Dhamtaritahsil by chief leaders and nationalists. This assembly was addressed by Pt. Sundarlal Sharma, Narayan Rao Medhawale and BabuChotelal Srivastava. They made aware of the torture of English Govt. and said to protest against them. ${ }^{22}$ When the villagers stared to react against Govt., then the British Govt. took the help of torture and thus cattle of villagers were captured in order to fulfill the amount. British Govt. made a plan to sell all these cattle and thus first of all cattle were taken to the Sunday Bazaar of Kandel village in Dhamtari tahsil. ${ }^{23}$ This time onwards people were awoke about their rights, however nobody was ever ready to buy these cattle; as a result all the efforts of British Govt. was in vain.

When the Govt. saw that, people of Dhamtari tahsil were politically becoming aware for their nation, and then Govt. decided to suppress them down. Thus Babu Chotelal Srivastava and his cousin Lalji Babu and other chief farmers of Kandel village and other nationalists of the tahsil were arrested and people were beaten up. ${ }^{24}$ But all these nationalists without fear came forward and accepted their torture. During this critical moment chief leaders of this tahsil focused towards well known a great leader of India M. K Gandhiji, and decided to offer this Satyagraha. After the death of Bal Gangadhar Tilak, August $1920^{25}$ all the responsibilities of Satyagraha came on the shoulders of Gandhiji. Kandel Nahar Satyagraha was continued for five months. Thus, at last chief leaders were requested by writing a letter to Gandhiji, and Gandhiji with tender heart accepted to come to Dhamtari tahsil; at this time Gandhiji was in tour of Bengal. In the month of Dec. 1920 one of the chief leaders of this tahsil called Pt. Sundarlal Sharma went to Calcutta to bring Gandhiji. ${ }^{26}$

\section{Concluding Remarks}

On the other hand from district headquarter Raipur, Deputy- Commissioner along with the officers of Irrigation department reached to Kandel village. After the investigation it was found the truth in favor of Kandel villagers. Thus the accusation was false. ${ }^{27}$ The fault of Govt. was hidden within them; there was the end of the Satyagraha. ${ }^{28}$ At the end cattle of villagers were left free and no amount was taken from villagers. Finally, before the arrival of Gandhiji into the tahsil, Satyagraha was successfully ended up in favor of villagers as well by this Satyagraha people of these areas were motivated.After the success of Kandel Satyagraha, arrival of Gandhiji took place in the Dhamtari tahsil and Gandhiji motivated all people for attaining of Swaraj. In the national movement of India, Kandel Satyagraha played a notable and remarkable role for attaining of the final goal - Swaraj.

\section{References:}

[1]. Dr. Ramgopal Sharma, Chhattisgarh Ke Raipur Jile Main Swatantra Sangram Andolan, Sain Prakashan, Dhamtari, Raipur, 1994, P.28.

[2]. Dr. Ashok Shukla, Chhattisgarh Ka Rajnitik Itihas Evam Rashtriye Andolan, Yogbodh Prakashan, Raipur, P.98.

[3]. Ibid., P.98.

[4]. Dr. Ramgopal Sharma, and Dr. Taru Tiwari, Chhattisgarh Ka Prashashan Evam Swatantra Sangram Andolan (1854-1947), P.24.

[5]. Dr. Ramgopal Sharma, Dr. Taru Tiwari, Chhattisgarh Ka Prashashan Evam Swatantra Sangram Andolan (1854-1947), P.25.

[6]. Ramnarayan Mishra, Harshul Ki Dairy, Sanskaran, Pandulipi (Unpublished), PP. 21-31.

[7]. Shobharam Dewangan, Dhamtari Nagar Evam Tahsil Ka Swatantra Sangram Andolan, Pandulipi (Unpublished), PP. 14-15.

[8]. Pt. Govind Rao Hardikar, Pt. Madhav Rao Sapre, Hindi Sahitya Sammelan Prakashan, Raipur, 1950, PP.112-113.

[9]. Ibid., P. 113.

[10]. Usha Yadav, Raipur Jile Main Swatantra Sangram Andolan Ke Do Sopan, Laghushodh Prabandh, Guru Ghasidas University, Bilaspur, 1989-90, P.28.

[11]. Dr. Arvind Sharma, Chhattisgarh Ka Rajnitik Itihas, P.83.

[12]. Rajesh Agnihotri, Chhattisgarh Main Savinay Awagya Andolan, Laghushodh Prabandh, Guru Ghasidas University, Bilaspur, P.11.

[13]. Shobharam Dewangan, Dhamtari Nagar Evam Tahsil Ka Swatantra Sangram Andolan, P. 14.

[14]. Dr. Ramgopal Sharma, and Dr. Taru Tiwari, Chhattisgarh Ka Prashashan Evam Swatantra Sangram Andolan (1854-1947), P.32.

[15]. Ibid., P.33.

[16]. Dr. Sureshchandra Shukla, and Dr. Archana Shukla, Chhattisgarh Ka Samagra Itihas, P.216.

[17]. Dr. Ramgopal Sharma, Chhattisgarh Ke Raipur Jile Main Swatantra Sangram Andolan, P.35.

[18]. Prinath Tiwari, Chhattisgarh Main Asahyog Andolan, Laghushodh Prabandh, P.13.

[19]. Dr. Ramgopal Sharma, Chhattisgarh Ke Raipur Jile Main Swatantra Andolan, P.100.

[20]. Dr. Usha Yadav, Chhattisgarh Ki Pichli Jatiyon Ka Rashtriye Jagran Main Yogdan, Ph.d.ShodhPrabandh (Unpublished), 19992000, Guru Ghasidas Bilaspur, PP.81-82.

[21]. Hari Thakur, Chhattisgarh Per Gandhiji Ke Byaktitva Ka Prabhav (Chhattisgarh Main Gandhiji Se Sabhar - published in 1970 by Pt. Ravishankar University, Raipur), P.9.

[22]. Records from Tahsil Congress Committee, Dhamtari.

[23]. At present there, Etwari Bazar took place.

[24]. Shobharam Dewangan, Dhamtari Nagar Evem Tahsil Ka Swatantra Sangram Andolan, P.19.

[25]. Dr. Usha Yadav, Chhattisgarh Ki Pichli Jatiyon Ka Rashtriye Jagran Main Yogdan, P.84.

[26]. Anil Kumar Bajpaye, Chhattisgarh Main Janjagran Ke Praneta Pt. Sundarlal Sharma Ka Byaktitva VaKrititva, P.65.

[27]. Priyenath Tiwari, Chhattisgarh Main Asahyog Andolan, P.17.

[28]. Dr, Ramgopal Sharma, Chhattisgarh Ke Raipur Jile Main Swatantra Sangram Andolan, P.106. 